\title{
THE WAY TO DETERMINE THE APPROXIMATELY HAIL'S DIMENSIONS
}

\author{
Nicolae ILIE ${ }^{1,2}$, Liviu APOSTOL ${ }^{2}$, Aurel Dănuț AXINTE ${ }^{1}$
}

Keywords: convective clouds; Skew-T diagram; equilibrium level; updraft; hail; clouds track

\begin{abstract}
To determine those storms associated with the convective clouds is necessary a good knowledge of the vertical profile of the troposphere. To determine this parameter, it's essential to make the Skew-T diagrams. From these, we can extract useful information relating to the level of free convection (LFC), the equilibrium level (EL), and the maximum speed of the updraft. The parameter brought in the discussion is handy to hail's forecast. Therefore, based on this parameter, of the ascendant airflow flux, it can determine the dimension of the hail. Besides to determine the hail's sizes, from Skew-T diagram we can find other parameters, such as the Total Totals Index (TTI), this being useful to decide on the coverage rate of the storms, the K Index (KI) - helpful in the case of convections who occur in the same air-mass. The Skew-T diagrams are useful to determine the conductor flux's speed and direction; this is situated between 700 to 500 $\mathrm{hPa}$ geopotential heights. Noteworthy are the synoptically materials, by analyzing the way of disposing of the isobars who can be a good indicator of the severity of the storm. Also, the synoptically materials examine at the $500 \mathrm{hPa}, 300 \mathrm{hPa}$, and $200 \mathrm{hPa}$ geopotential to notice if occur the 'cut-off low' areas in the high troposphere. To see if a cloud system is dangerous of hail will be following the cloud's top temperature.
\end{abstract}

\section{INTRODUCTION}

The convective processes are the result of many facts such as water vapors in the atmosphere (Horgan et al. 2007), air-temperature, the updraft, and the evolution of the synoptically patterns. Their meeting is favorable to convective

1 Unit of Hail Suppression Moldova 1 Iasi, Romania; nyycu_87@yahoo.com; axinte_dan@yahoo.com

${ }^{2}$ Alexandru Ioan Cuza, University of Iași, Faculty of Geography and Geology, Iaşi, Romania; apostolliv@yahoo.com 
developments, which, many times, can generate damages or even injuries. This study shows the way by which we can forecast the approximate dimensions of hail in the high reflectivity area from the cloud.

The geographical position of Moldavia at the level of Romania is one favorable of the convective process' development. This region is situated on the eastern side of the Carpathian range. The characteristic shown here, given by the shape of Wooded Carpathians (Ukraine) and Eastern Carpathian (Romania), favors the cold air-mass' movement from the Northern Sea and north side of Atlantic towards the studying region. So, the air-mass with its characteristics shows a movement from west-northwesterly towards eastsoutheasterly. This movement takes place over the German-Poland Plain. The contact area constituted between German-Poland Plain and Wooded/Eastern Carpathian is one favorable to change the mainstream of the air-masses movement. That new direction becomes one from north-westerly to south-east. In doing so, based on the 'Coandă Effect' (Bordei-Ion N., 1988, Apostol, Sfîcă, 2013), the cold air-mass will advance toward Moldavia where will replace the previously warm air-mass. This context is favorable to develop huge convective clouds.

The phenomenon of convection in Romania was overestimated, but without arguments. Hârjoabă, Crețu (1984), determine that the phenomenon produces less than $5 \%$ of the annual amount of precipitation. But there is also convection on the frontal surfaces, overall, the convection producing higher amounts of precipitation, visible fact by hourly analysis of precipitation quantities (Apostol, 2000, Apostol, 2004). The high percentage of precipitation quantities produced by the thermo-hydric convection is also suggested by the high percentage of the precipitations in the hot semester, compared to those in the cold semester (Apostol, 1987).

Alongside the synoptically pattern, in the evolution of convective processes at the level of the studied area, the importance is shown by local facts, such as topography or lakes. The vegetation plays an essential role in convective thermodynamic processes at the regional scale. That role is highlighted by moisture surplus, aspect what's noticed best during May and June, a period when the vegetation is at its maximum level of the development (Marsham et al. 2008).

By the studies made at the studied region's level, the numbers of days with hail falls are between 0.8 and 1.2, especially outside of the Carpathian Range (Machidon, 2009; Apostol, Machidon, 2009).

Making such forecasts regarding hail's dimensions is one very important for hail suppression units. In conformity with these forecasts, in the frame of recalled units can be approached the most appropriates strategies to diminish 
the damages caused by hail falls on-farm areas and not only. Moreover, the hail' forecast involves besides proper process, highlighting of other characteristics of convective clouds, such as the speed of updraft, base of convections, or level of free convection - LFC, and the superior part of the cloud, or the equilibrium level - EL. Also, we can determine other parameters such as the direction and speed of the cloud's movement, associated air-mass. Here, we can speak about types of convective clouds, such as unicellular or multi-cells related to the same air-mass. Besides, we can take into account those associated with a squall line, such supercells or even a mesoscale convective system - MCS.

\section{DATA AND METHODS}

To accomplish a hail forecast, the first tool to determine that is the Skew$\mathrm{T}$ diagram (fig. 1). By that it can follow the evolution of the thermodynamic facts on the vertical section where is contained all of the troposphere. Concretely, it can be identified the level of free convection - LFC, the area where it's anticipated the highest values of updraft, and the equilibrium level EL.

On the shown material, they can identify the following parameters, useful to determine the approximately hail's dimension in the cloud:

1 - Line drown at $\mathrm{Tw}$ with mixing ratio; 2 - Line drown from $\mathrm{T}$ in accordance with the dry adiabatic; 3 - The base where the clouds are developed (LLC); 4 - Base of level of free convection (LFC); 5 - The place where the updraft reaches its maximum speed (W); 6 - The place where the convective cloud enters its maximum phase of development, top or equilibrium level (EL); 7 - level of $700 \mathrm{hPa} ; \mathbf{8}$ - level of $500 \mathrm{hPa}$; Those two level are crucial to determine the speed and movement direction of clouds.

Once found all necessary parameters, it's used the following formula (1) to determine the approximate speed of updraft marked with 5 on the Skew-T diagram.

$$
\mathbf{W} \mathbf{m}=\frac{\sqrt{2 * R * C p *\left(T^{\prime}-T\right) * \lg \left(\frac{T \mathrm{LFC}}{\mathrm{TWMax}}\right)}}{2},(1), \text { where: }
$$

$\mathbf{R}$ - The universal constant of gases; $\mathbf{C p}$ - The caloric capacity of air; (T-T') - Difference between temperatures of environment bounded by the LFC and air; Ig (TLFC/TWmax) - decadic logarithm from rapport of level free convection pressure $\left(\mathbf{T}_{\mathbf{L F C}}\right)$, and the place where it's expecting the maximum speed of updraft (TWmax). 


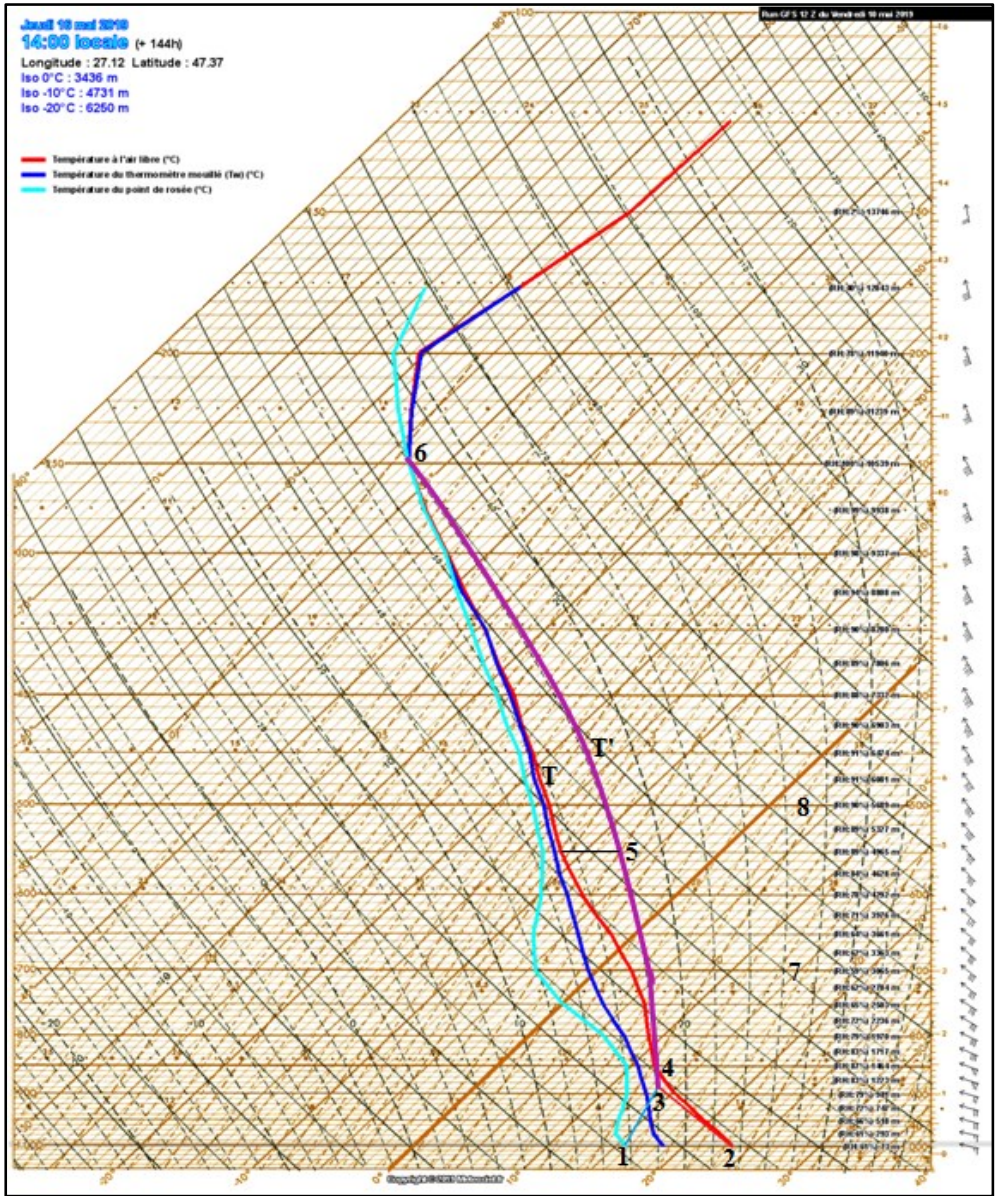

Figure 1. The way to determine the convective process with the Skew-T diagram's aid. (https://www.meteociel.fr/modeles/gfse_3d.php?lat=46.32\&lon=25.44\&ech=6\&zoom=2.2)

Once computed this value, to find the updraft's values, the result will be divided at two. From the moment when we found that value, it's possible to forecast the appropriate values of hail in the place of cloud characterized by maximum values of reflectivity. To find this, we'll use the following formula (2):

Cm_hail $=2 *((3 * 0.55 * 1.0033 *(\mathrm{Wm} * \mathrm{Wm}) /(8 * 9.8 * 900)) * 100$, (2). 
Besides of hail dimensions' compute, essential to forecast the convective processes are the follows indices of instability: Total Index (TT) and K Index (KI). To apply the TT index can be found the spread and severity of storm. To compute this index will be applied the following formula (3):

$$
\mathrm{TT}=(\mathrm{T} 850-\mathrm{T} 500)+(\mathrm{Td} 850-\mathrm{T} 500)
$$

Values found with this formula will be compared with namely thresholds, as follows:

TT < 44: thunderstorms unlikely; TT 44 to 45 : isolated thunderstorms; TT 46 to 47: scattered thunderstorms; TT 48 to 49: scattered thunderstorms, isolated severe thunderstorms; TT 50 to 51: few thunderstorms, scattered severe thunderstorms, isolated tornadoes; TT 52 to 55: few to numerous thunderstorms, scattered to few severe thunderstorms, isolated to scattered tornadoes; TT > 56: numerous thunderstorms, few severe thunderstorms, scattered tornadoes. (https://www.skystef.be/calculator-totaltotalsindex.htm)

The $\mathrm{K}$ index is a good indicator to determine the severity of storms in the frame of the same air-mass. This study, being an experiment to forecast the hail' dimensions during May and June 2019, also contain those types of storms which have generated themselves in the same air-mass.

To compute the recalled indicator, we'll use the following formula (4):

$$
\mathrm{K}=(\mathrm{T} 850-\mathrm{T} 500)+\mathrm{Td} 850-(\mathrm{T} 700-\mathrm{Td} 700),(4)
$$

Valid for $3^{\text {rd }}$ and $4^{\text {th }}$ formulas: $\mathbf{T 8 5 0}$ - The air-mass parcel temperature at $850 \mathrm{hPa}$ level; T700 - The air-mass parcel temperature at $700 \mathrm{hPa}$ level; T500 - air-mass parcel temperature at $500 \mathrm{hPa}$ level; Td850 - The dew-point temperature at $850 \mathrm{hPa}$ level; Td500 - The dew-point temperature at $500 \mathrm{hPa}$ level.

Similarly with the previously index, the values found will be compared with namely thresholds as follow:

KI <20: thunderstorms unlikely; KI 20 to 25: isolated thunderstorms; KI 26 to 30: scattered thunderstorms; KI 31 to 35: few thunderstorms; KI 36 to 40: few to numerous thunderstorms; KI > 40: almost $100 \%$ risk for thunderstorms. (https://www.skystef.be/calculator-k-index.htm).

Besides those shown, by importance at the convective clouds' forecast is the speed and movement of air-mass. To determine those parameters, by importance were the values of air-masses movements at 700 and $500 \mathrm{hPa}$ geopotential. So, for speed was used the following compute formula (5): 


$$
\begin{array}{r}
\mathbf{V m}=(700 \mathrm{hPa}+500 \mathrm{hPa}) / 2 \\
\mathbf{V} \text { _movement }=(\mathbf{V m} * 0.83)+3.6 \\
V-\text { Speed }
\end{array}
$$

\section{RESULT AND DISCUSION - CASE STUDIES}

\section{May $19^{\text {th }}, 2019$}

The day of May $19^{\text {th }}, 2019$ was characterized by warm weather, but into a cyclonic synoptically pattern. The air-mass movements during that day prevailed from the south-easterly sector, fed with moisture from the western side of the Black Sea. The presence of low-atmospherically areas over the Mediterranean Sea, meantime with an anti-cyclonic area placed over the eastern and north-eastern parts of Europe, drove to the development of troughs placed at the East and North-Eastern part of Romania. (fig. 2).

The meteorological-synoptically pattern illustrated has driven to develop very well organized convective cells in the Eastern part of Romania, more accurate over the Moldavia territory. All of those were associated with the troughs shown. Based upon thermodynamic processes' studies in the troposphere, were favorable conditions to develop huge convective clouds with high disruptive potential.

The afternoon of May $19^{\text {th }}, 2019$, shows very high indicators for storms, such as the lifted index (LI) with values who went down under -8 to -6 . CAPE (Convective Available Potential Energy) exceeded $2100 \mathrm{~J} / \mathrm{kg}$. Besides, the Total Index (TTI) shown values of 51 to 54, a fact that characterized the day with very many storms, one of them was severe. Also, high values for K Index (KI) with values of 31 to 34 what means that there were convective clouds structures by cluster type.

Based on the previous material shown (fig. 3), it can notice a comprehensive development of the convective clouds. The base of free convection at the local level (LFC) situated at $1400 \mathrm{~m}$ altitude that means an equivalent of $864 \mathrm{hPa}$. The superior part of convections has placed at $11150 \mathrm{~m}$ altitude, with a temperature of the cloud top around $-57^{\circ} \mathrm{C}$. The place with maximum updraft estimated at $7900 \mathrm{~m}$ high or $360 \mathrm{hPa}$, conditions where the speed of the parameter has shown values between 28 and $32 \mathrm{~m} / \mathrm{s}$. In those conditions, the hail' dimensions into the place with a high rate of updraft were around 3.7 to $4.4 \mathrm{~cm}$ in diameter. 


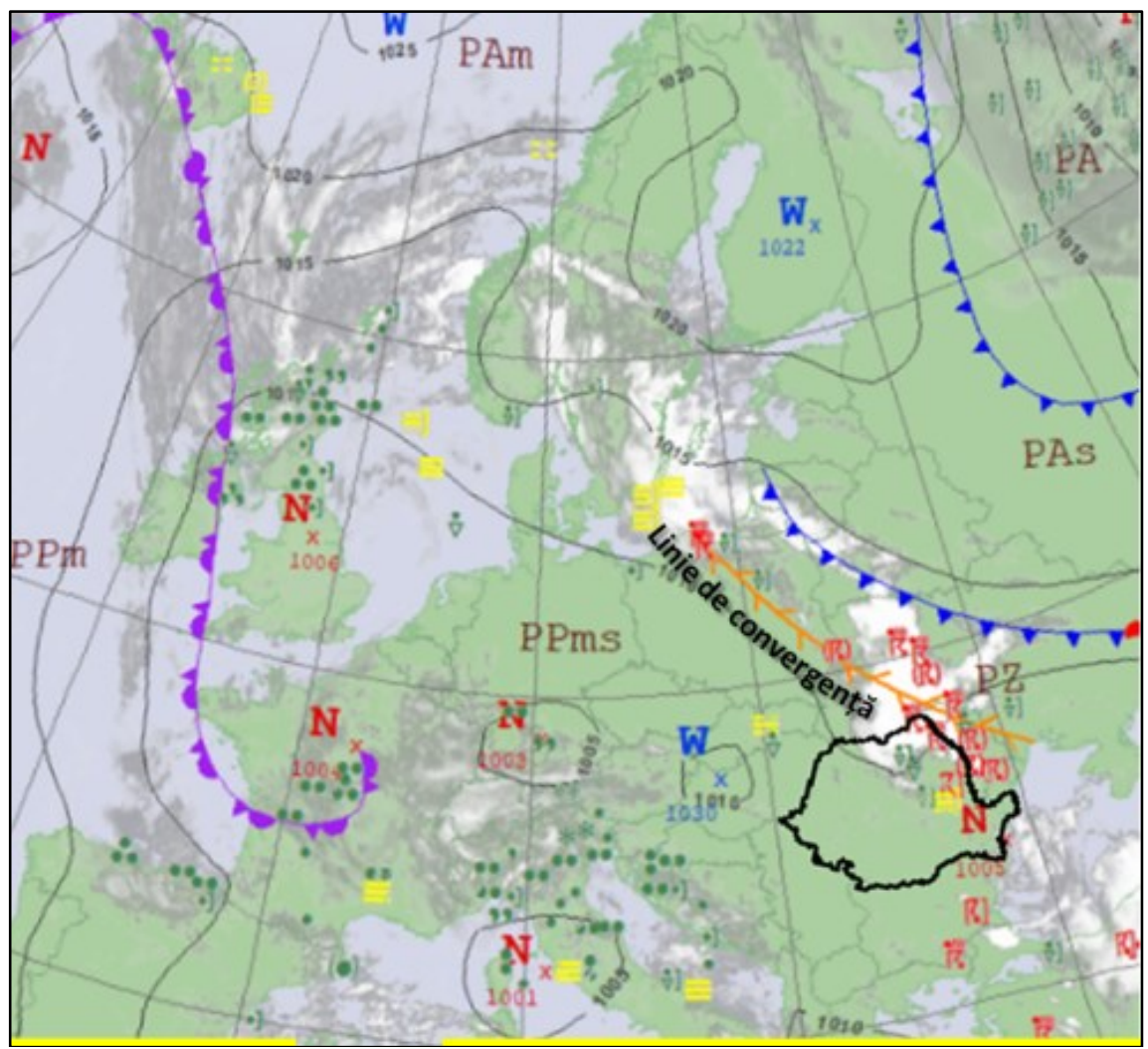

Figure 2. The synoptically context in Europe for May 19 ${ }^{\text {th }}, 2019$ at 12:00 UTC Credit: https://www.facebook.com/Meteo.Moldova and http://www.pogodynka.pl

The speed of convective cells' movements was between 25 and $29 \mathrm{~km} / \mathrm{h}$ from the south-south-eastern part (azimuth 155 to $170^{\circ}$ ). 


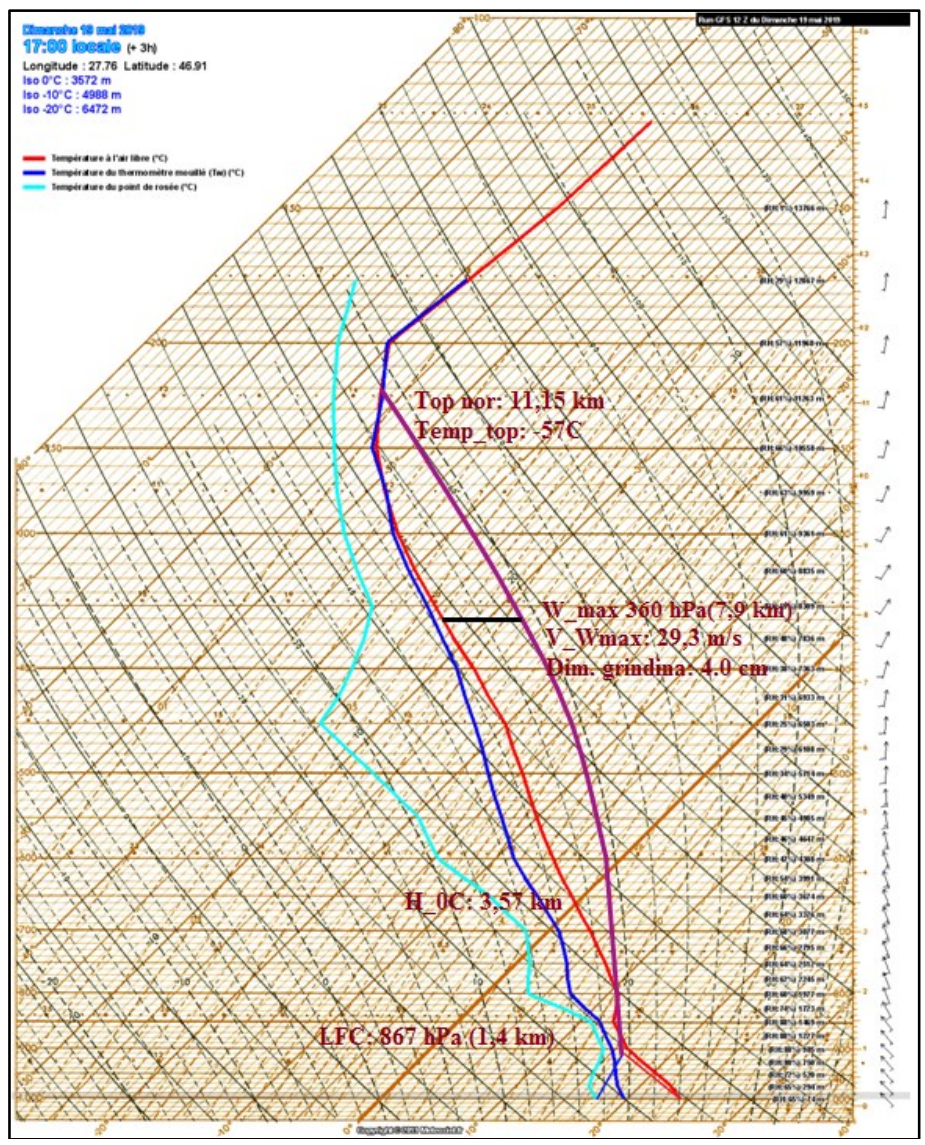

Figure 3. The thermodynamically in the Eastern part of Moldavia, May 19 $9^{\text {th }}, 2019$, 15:00 UTC

The convective process forecast with anticipation around 5 to 6 hours is validated with the RADAR aid, product available for the Moldavia area (fig. 4). 

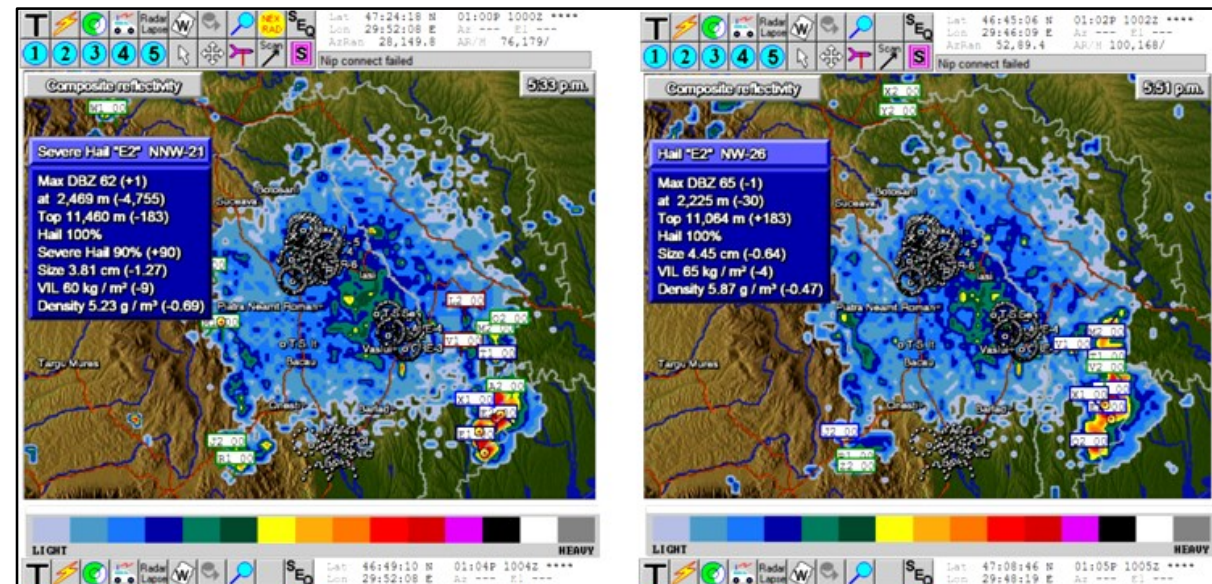

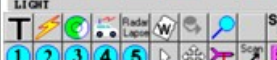
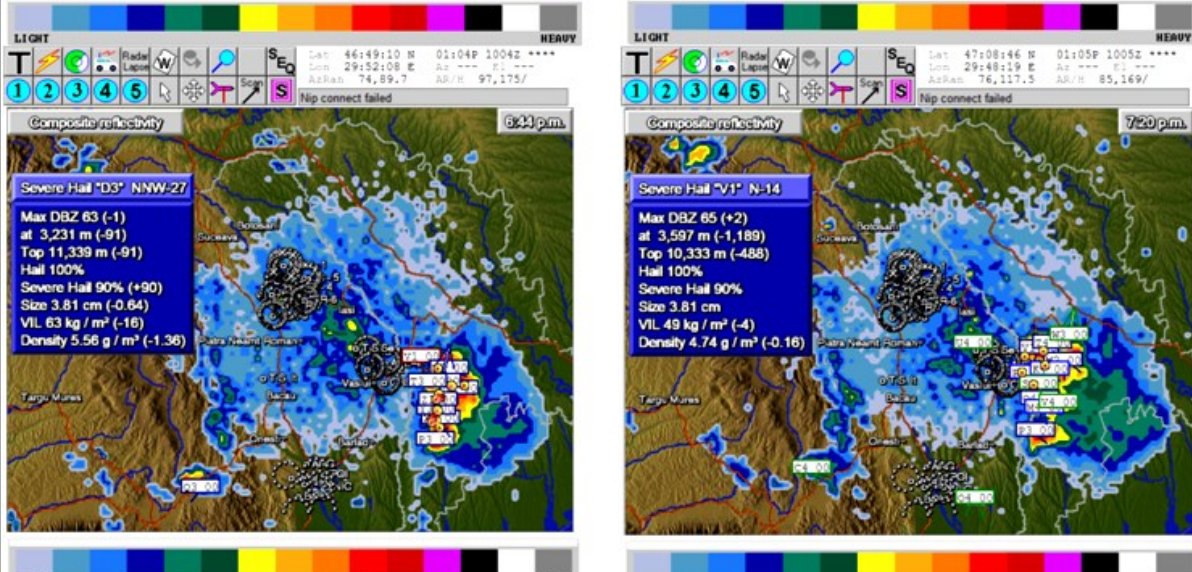

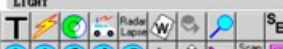
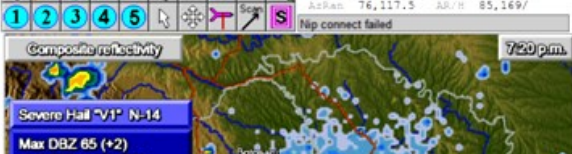

Max D8Z $65(+2)$

Top 10,333
Hall $100 \%$

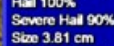

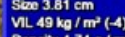

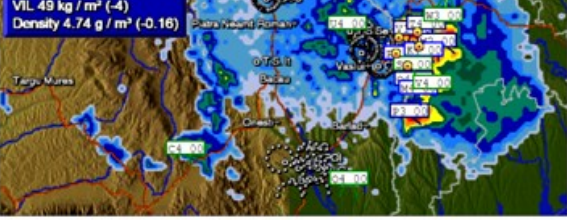

LIan

Figure 4. RADAR data from Bârnova ( Iași County) available for Moldavia area on May $19^{\text {th }}, 2019$. Credit: WSR-98D from National Weather Administration Network via U.C.C.G 'Moldova 1' Iași

May $20^{\text {th }}, 2019$.

Previously day was characterized by a movement toward north-northeastern of a Mediterranean low-depression that associated with an atmospherically cold front. That has crossed the geographical area of Moldavia during the evening and the next night. On the front side of the low-depression were favorable conditions for locally convective developments. Alongside the low-depression area, in the Eastern part of Europe was active in a highpressure area (fig. 5). The coupling between those two synoptically areas were favorable for warm and moist air-masses over the Romania territory. 
For this interval, the process of anticipating all the convective parameters was made with 24 hours in advance. So, based on the analyzed parameters on the Skew-T diagrams, the convective processes have shown values very high. The lifted index (LI) was between -5 to -4 and CAPE by 1300 to $1600 \mathrm{~J} / \mathrm{kg}$. Moreover, the Total Index (TTI) has shown values which placed between 51 and 53 where the convective clouds generated, locally, severe storms. Because on that day was a frontal passage, the K Index (KI) doesn't show any relevance. This index (KI) is available only then we are speaking about the atmospherically instability in the same air-mass.

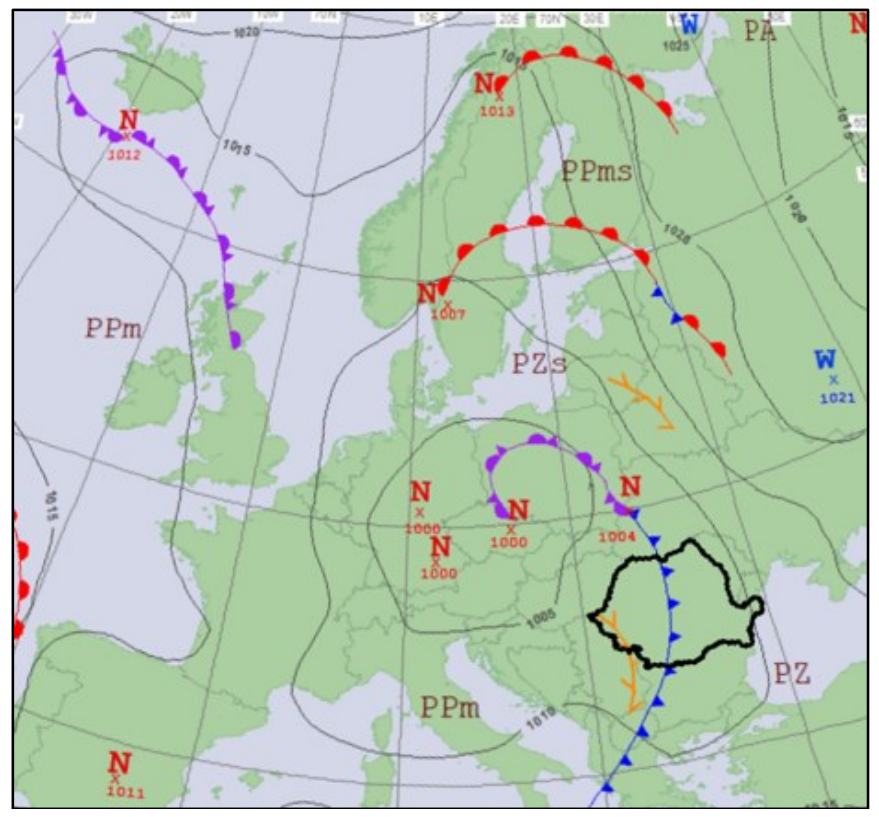

Figure 5. The synoptically context in Europe for May 20 ${ }^{\text {th }}, 2019$ at 12:00 UTC Credit: http://www.pogodynka.pl

From the making of the present forecast had resulted in the hail's dimensions into the clouds over the northern part of Moldavia by 3.0 to $3.7 \mathrm{~cm}$ in diameter. The most common values were those by $3.4 \mathrm{~cm}$ in width, where the updraft showed the maximum speed, around 25 to $29 \mathrm{~m} / \mathrm{s}$ - the interest area placed at 7500 to $7900 \mathrm{~m}$ heights or equivalent of $370 \mathrm{hPa}$. (fig. 6).

The local free of convection placed at $1160 \mathrm{~m}(886 \mathrm{hPa})$ and the equilibrium level (EL) or the top of the cloud, set at $11400 \mathrm{~m}$ and temperature by $-58^{\circ} \mathrm{C}$. The average speed of clouds' movement was between 55 and 60 
$\mathrm{km} / \mathrm{h}$ from south to north (azimuth 170 to $185^{\circ}$ ). The high values of the movements indicate that the convective clouds were associated with a cold front advance about who we talked.

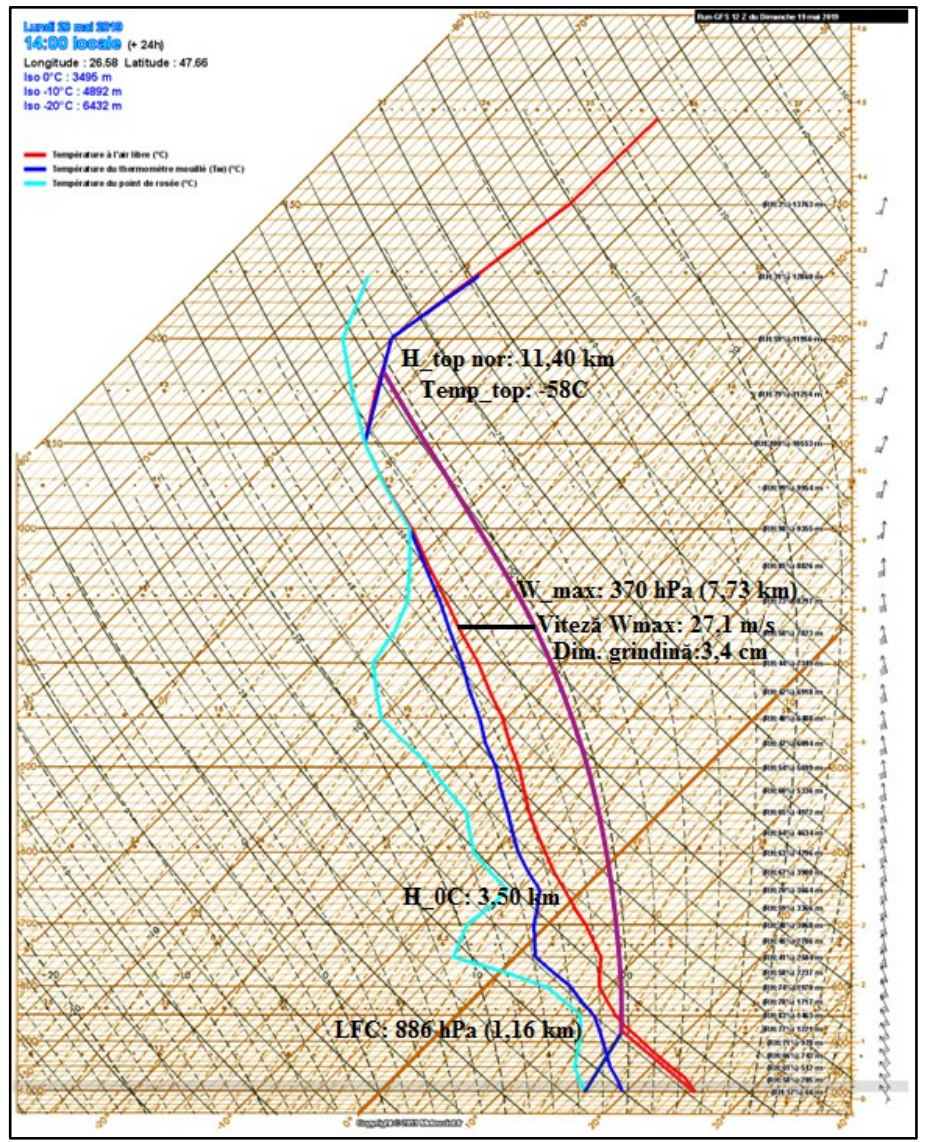

Figure 6. The thermodynamically in the Eastern part of Moldavia, May $20^{\text {th }}, 2019$, 12:00 UTC

All of those illustrated on the forecast materials with 24 hours in advance was checked, with some variations of the convective clouds movement's speed. So, on the weather forecast made back with a day, the speeds waited were around 55 to $60 \mathrm{~km} / \mathrm{h}$. The real values, following the RADAR material, were just 38 to $45 \mathrm{~km} / \mathrm{h}$. All the other parameters forecasted conformed to the results displayed by RADAR (fig. 7). 
An important feature is that represented by Carpathian Range. They have some particular aspects regarding the thermodynamically locally features. So, all of those aspects can't be taken into account on the prompt resolution of numerical atmospherically models.
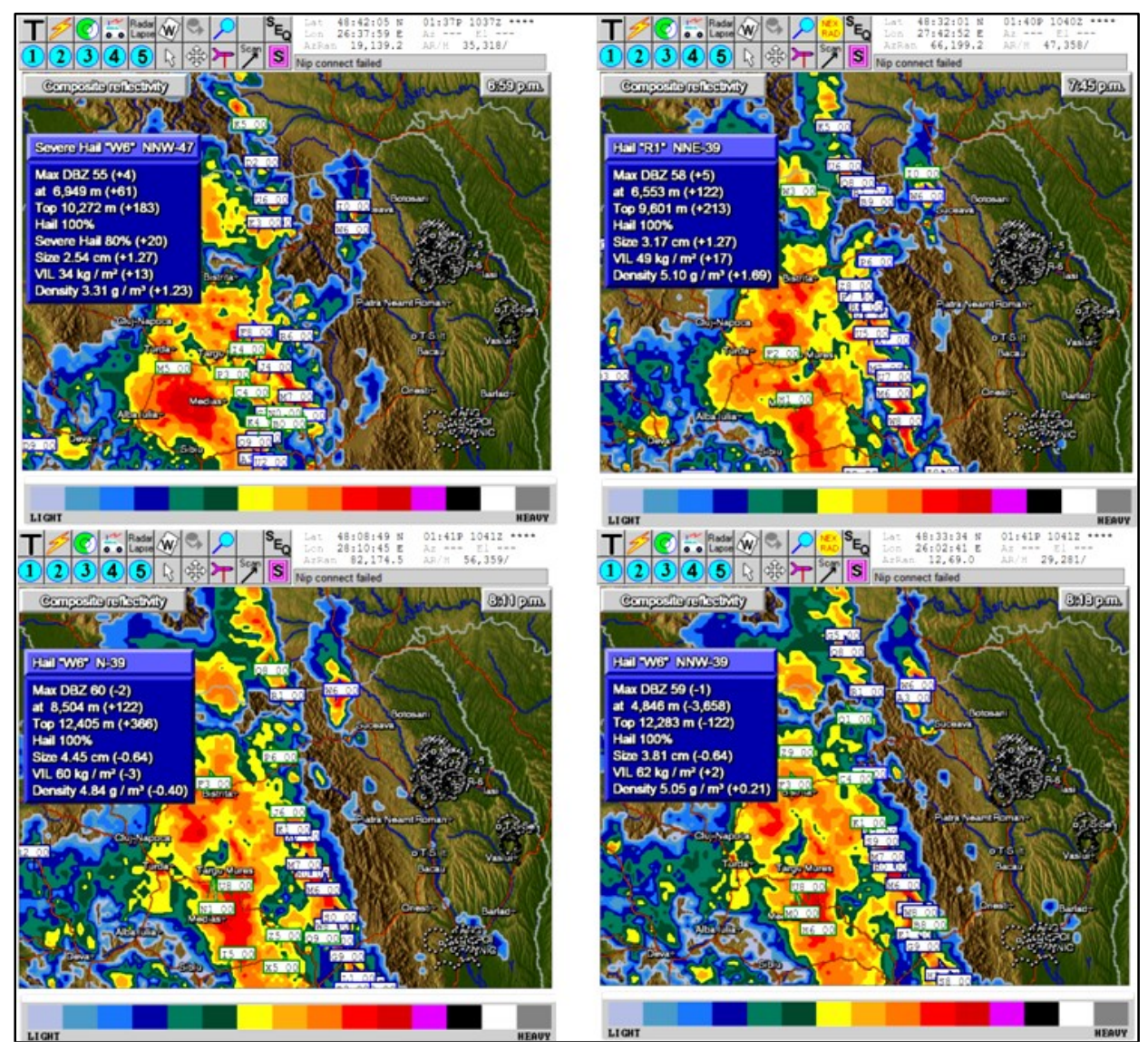

Figure 7. RADAR data from Bârnova ( Iași County) available for Moldavia area on May 20 $0^{\text {th }}$, 2019. Credit: WSR-98D from National Weather Administration Network via U.C.C.G 'Moldova 1' Iași

June, $3^{\text {rd }}, 2019$.

A high rate of atmospherical instability characterized in June 2019. During this month over the south-eastern and central south-eastern part of Europe prevailed in the low-atmospherically areas. Romania situated into the warm sector of those depressions. As a result, there was a warm and humid 
weather pattern, the leading cause of the storms, more of them in the same airmass.

Regarding June $3^{\text {rd }}$, 2019, Romania's geographical area situated over the north-north-eastern side of a low-depression area that was centered somewhere over the northern part of the Balkan Peninsula. On this synoptically pattern illustrated (fig. 8), towards Romania were favorable warm and moist airmasses advection from south-eastern. All of those air-masses' characteristics were associated with crossing the western part of the Black Sea. The high intensity of the warm air-mass advection and the cyclonic regime were ideal for generating an upper trough, that ideal for tall and severe convection processes.

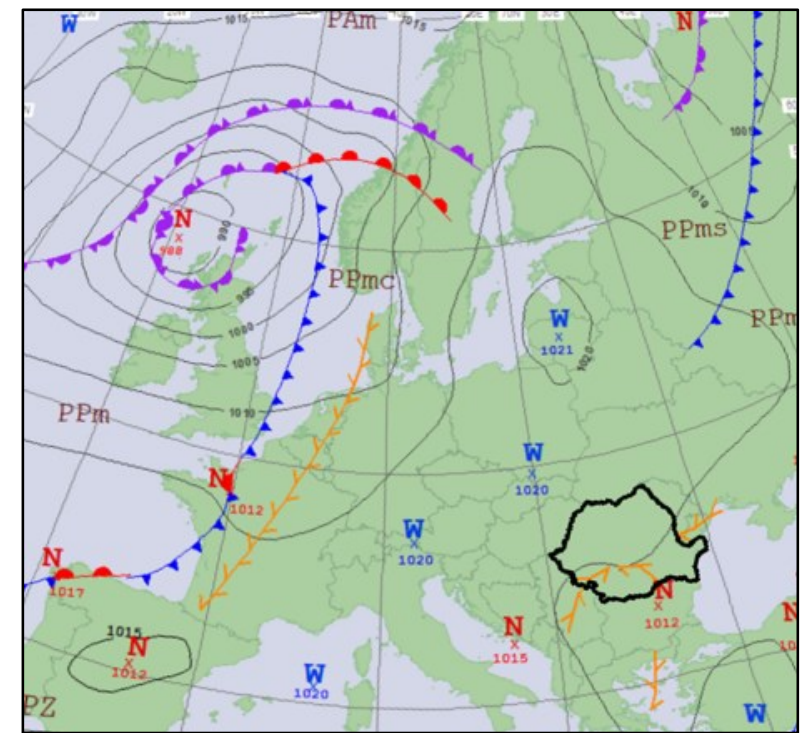

Figure 8. The synoptically context in Europe for June $3^{\text {rd }}, 2019$ at 00:00 UTC Credit: http://www.pogodynka.pl

For the reference day, the hail's forecast and other parameters associated with convective processes made with 26 hours in advance. So, the level of free convection placed at $1560 \mathrm{~m}$ height and the top of the cloud, or equilibrium level, was at $10580 \mathrm{~m}$. The temperature at this level of cloud was around $-52^{\circ} \mathrm{C}$ (fig. 9).

The hail's dimensions anticipated were, on average, by 2.0 to $3.0 \mathrm{~cm}$ in diameter, all of those at approximately 5500 to $5800 \mathrm{~m}$ where the speed of the updraft was by 20 to $23 \mathrm{~m} / \mathrm{s}$. The K Index (KI) values were around 33 to 35 
and 51 to 53 for the Total Index (TTI). That characteristic has shown that locally, the storms were intense. LI was around -3 to -2 and the convective potential, or CAPE, by 1200 to $1400 \mathrm{~J} / \mathrm{kg}$. The average speed of convective cells' movement was forecasted to reach speeds around 10 to $15 \mathrm{~km}$ from south-eastern, generally (azimuth 130 to $145^{\circ}$ ).

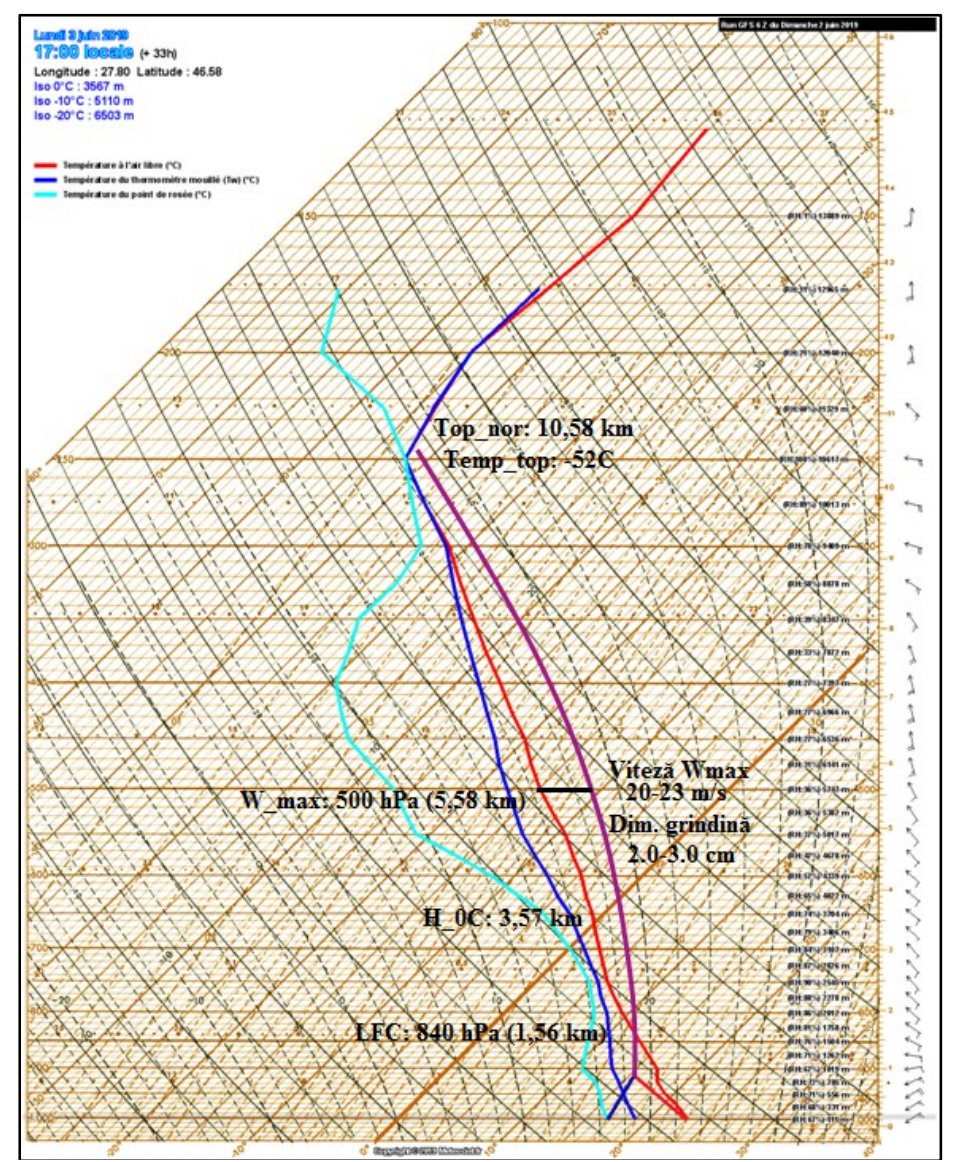

Figure 9. The thermodynamically in the Eastern part of Moldavia, June $3^{\text {rd }}, 2019$, 15:00 UTC

All of those shows were validate in the right way, the proof being the values on the day displayed by the weather RADAR (fig. 10). 

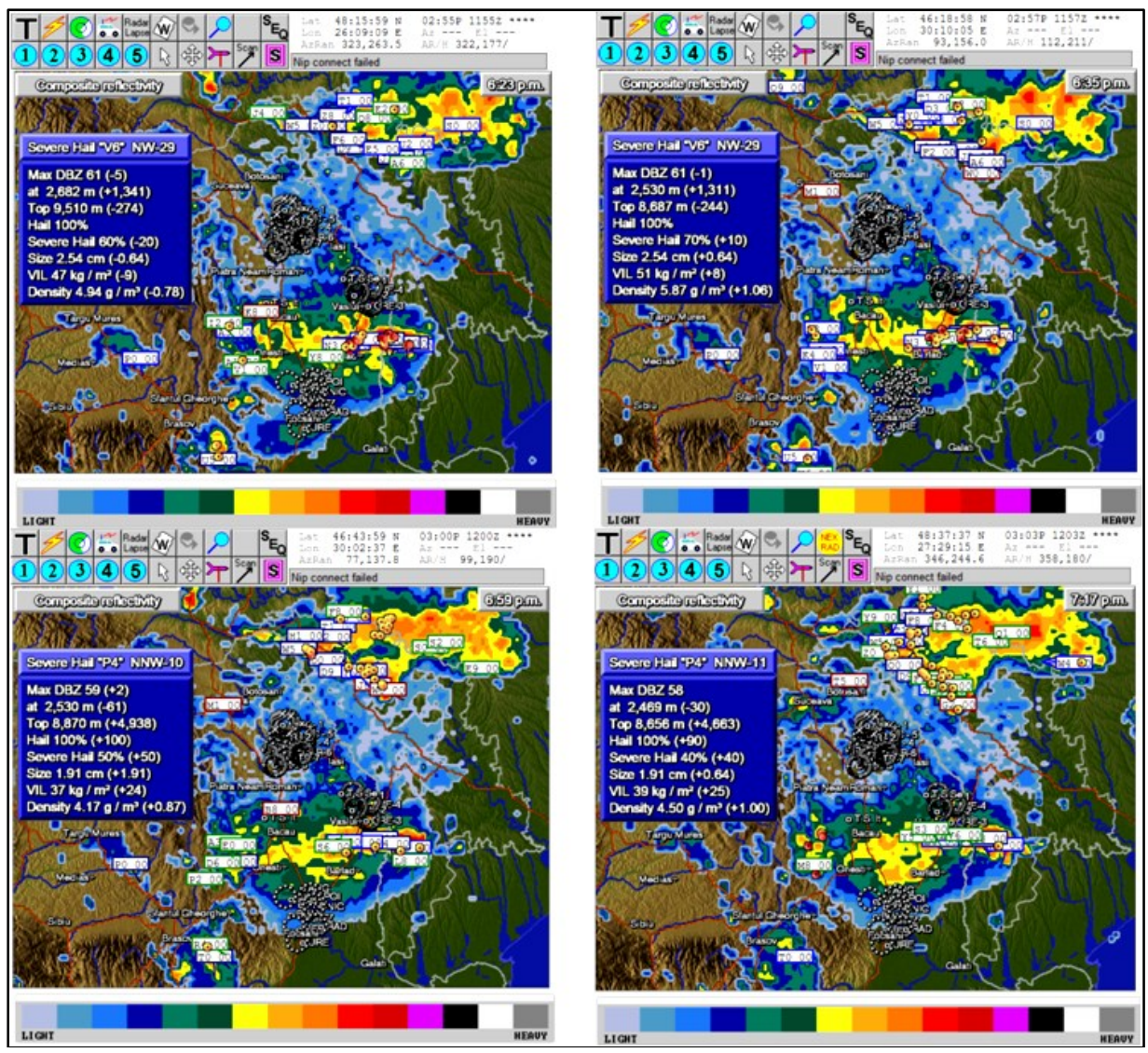

Figure 10. RADAR data from Bârnova ( Iași County) available for Moldavia area on June, $3^{\text {rd }}, 2019$. Credit: WSR-98D from National Weather Administration Network via U.C.C.G 'Moldova 1' Iași

\section{CONCLUSIONS}

In this paper, it can notice that the forecast of storms associated with hail can be made with $6 ; 12 ; 18$ or even 24 hours in advance. The rate in which all of those predictions can be made is around 85 to $90 \%$.

Besides, for a perspective, it's shown a table (tab.1) who illustrates, beside dimensions of hail, other parameters such speed and direction of convective cells, the reflectivity, the thickness of convective cells, and the temperature of the cells' top. 
Table 1. A comparison between forecasted parameters and those shown by RADAR WSR-98D Bârnova, Iasi County

\begin{tabular}{|c|c|c|c|c|c|c|c|c|c|}
\hline Data & Prognoze/RADAR & Interval anticipare & Oravizata & Vitera deplasare & Directie deplasare & Dimensiune medie grindina (nor) & Reflectivitate & Top & Temp top \\
\hline \multirow{2}{*}{$19 \mathrm{mai} 2019$} & Prognoza & \multirow{2}{*}{ aprox,4ore } & \multirow{2}{*}{ 18.20LT. } & $22.25 \mathrm{~km} / \mathrm{h}$ & SSENNVV & $5,00 \mathrm{~cm}$ & $60.67 \mathrm{~d} 82$ & $11,33 \mathrm{~km}$ & .57 \\
\hline & RADAR (Validare) & & & 17.8 & NV & 3.7 & 63.6 & 11304,4 & 54.1 \\
\hline \multirow{2}{*}{$20 \mathrm{mai} 2019$} & Prognoze & \multirow{2}{*}{ aprox. 24 ore } & \multirow{2}{*}{ 17.18LT. } & $46.48 \mathrm{~km} / \mathrm{h}$ & SSENNV & $4,10-4,5 \mathrm{~cm}$ & $55-60 \mathrm{dbz}$ & $11,4 \mathrm{~km}$ & .58 \\
\hline & RADAR(Validare) & & & 42.2 & NNV & 3.4 & 58.0 & 10838.6 & .58 .6 \\
\hline \multirow{2}{*}{ 3iunie 2019} & Prognoza & \multirow{2}{*}{ aprox. 24 ore } & \multirow{2}{*}{ 15-18 LT. } & $10-15 \mathrm{~km} / \mathrm{h}$ & SENN & $2,0-3,0 \mathrm{~cm}$ & $55.65 \mathrm{dB2}$ & $10,58 \mathrm{~km}$ & .52 \\
\hline & RADAR (Validare) & & & 26.9 & NNV & 3.0 & 62.0 & 9913.6 & -46.5 \\
\hline
\end{tabular}

ACKNOWLEDGMENT: This work was co-funded by the European Social Fund, through Operational Programme Human Capital 2014-2020, project number POCU/380/6/13/123623, project title 'PhD Students and Postdoctoral Researchers Prepared for the Labour Market'

\section{REFERENCES}

1. Apostol, L. (1987), Consideraţii asupra raportului dintre cantităţile semestriale de precipitaţii în România, Lucr. Sem. geogr. „D. Cantemir”, nr. 7/1986, Iaşi, pg. 53-64.

2. Apostol, L. (2000), Precipitațiile atmosferice în Subcarpații Moldovei, Edit. Univ. "Ștefan cel Mare", Suceava.

3. Apostol, L. (2004), Clima Subcarpaților Moldovei, Edit. Univ. "Ștefan cel Mare", Suceava

4. Apostol L., Machidon, O.M. (2009), Consideraţii asupra fenomenului de grindină în bazinul hidrografic Bârlad. Analele ştiințifice ale Universității. "Ştefan cel Mare" Suceava, secțiunea Geografie, Vol. 18, p. 61-72.

5. Apostol, L., Sfîcă, L. (2013), Thermal differentiations induced by the Carpathian Mountains on the Romanian territory, Carpathian Journal of Earth \& Environmental Sciences, $\quad 8(2), \quad$ p.215-221. http://www.cjees.ro/viewIssue.php?issueId=21

6. Bordei-Ion, N. (1988), Fenomene meteoclimatice induse de configurația Carpaților în Câmpia Română, Edit. Academiei Române, București, România, p.224.

7. Hârjoabă, I., Crețu, L. (1984), Tentația convecției, Anal. Univ. "Al. I. Cuza”, ser. nouă, secț.II, b, geol.-geogr., t.XXX, Iași.

8. Horgan, K.L., Schultz, D.M., Hales, J.E. Jr., Corfidi, St.F., Johns, R.H. (2007), A Five-Year Climatology of Elevated Severe Convective Storms in the United States East of the Rocky Mountains, American Meteorological Society. Vol. 22, p. 1031 to 1044. DOI: 10.1175/WAF1032.1. https://doi.org/10.1175/WAF1032.1

9. IPCC (2014), Climate Change 2014: Mitigation of Climate Change: Contribution of Working Group III to the Fifth Assessment Report of the Intergovernmental Panel, Cambridge Univ. Press, p. 1132.

10. Machidon, O.M. (2009), Fenomenul de grindină în bazinul hidrografic Bârlad, Rez. tezei de dr., Univ. „Al. I. Cuza” Iaşi. 
11. Marsham, J.H., Parker, D.J., Grams, C.M., Johnson, B.T., Grey, W.M.F., Ross, A.N. (2008), Observations of mesoscale and boundary-layer scale circulations affecting dust transport and uplift over the Sahara, Atmos. Chem. Phys., No. 8, p. 6979-6993. https://doi.org/10.5194/acp-8-6979-2008

12.https://www.meteociel.fr/modeles/gfse_3d.php?lat $=46.32 \& l o n=25.44 \&$ ech $=6 \& z o o$ $\mathrm{m}=2.2$

13. https://www.skystef.be/calculator-totaltotalsindex.htm

14. https://www.skystef.be/calculator-k-index.htm

15. https://www.facebook.com/Meteo.Moldova

16. http://www.pogodynka.pl

C 2020 by the authors. Licensee UAIC, Iasi, Romania. This article is

(CC)
BY NC ND
an open access article distributed under the terms and conditions of
creativecommons.org/licenses/by-nc-nd/4.0).

(CC)
BY NC ND
an open access article distributed under the terms and conditions of
creativecommons.org/licenses/by-nc-nd/4.0). 